\title{
A novel fusidic acid resistance gene from Streptomyces lividans 66 encodes a highly specific esterase
}

\author{
Beate von der Haar, Stefan Walter, Susanne Schwäpenheuer \\ and Hildgund Schrempf
}

Universität Osnabrück, FB Biologie/Chemie, Barbarastraße 11, 49069 Osnabrück, Germany
Author for correspondence: Hildgund Schrempf. Tel: +49541969 2895. Fax: +495419692804. e-mail: schrempf@sfbbio1.biologie.uni-osnabrueck.de

\begin{abstract}
Resistance to fusidic acid in Streptomyces lividans is due to secretion of an extracellular enzyme (FusH) that converts the steroid antibiotic into an inactive derivative. $\mathrm{NH}_{2}$-terminal and several internal amino acid sequences were prepared from the purified enzyme. Using one of the deduced oligonucleotides to probe a subgenomic DNA library, the fusH gene was cloned and sequenced. Sequence analysis located an ORF which, owing to the presence of two putative start codons, indicates a predicted protein with $\mathbf{5 2 0}$ or 509 amino acids. A signal peptide was identified by aligning the deduced amino acids with the $\mathrm{N}$-terminal sequence determined for the mature enzyme. The C-terminal part of the deduced FusH contains a region of three tandemly repeated stretches of $\mathbf{5 0}$ amino acids, which is preceded and followed by amino acids showing high homology with the repeats. FusH was found to share a GDS motif with some deduced esterases. S. lividans transformants carrying fusH on a multicopy vector synthesized high levels of FusH. Purified FusH cleaved equally well an acetyl, a thioacetyl or a formyl group from the $16 \beta$-position of fusidic acid and its derivatives. However, a propionyl group at the 16 $\beta$-position was attacked with difficulty and a $16 x$-acetyl group was not hydrolysed at all. These data indicate that FusH is a highly specific esterase. The fusH gene is widely distributed among streptomycetes that modify fusidic acid to its inactive lactone derivative.
\end{abstract}

Keywords: Streptomyces lividans 66, fusidic-acid-inactivating enzyme, esterase (FusH), FusH gene

\section{INTRODUCTION}

Fusidic acid is a steroid-like antibiotic isolated from the fungus Fusidium coccineum (Godtfredsen et al., 1962). It is structurally related to helvolic acid from Aspergillus fumigatus (Waksman et al., 1943) and cephalosporin P1 from Cephalosporium sp. (Burton \& Abraham, 1951).

Fusidic acid binds to elongation factors EFG (Tanaka $e t$ al., 1969) and EF2 (Malkin \& Lipman, 1969) from prokaryotic and eukaryotic organisms, respectively. Spontaneous fusidic-acid-resistant strains from Staphylococcus aureus and certain Escherichia coli strains possess a modified EFG (Tanaka et al., 1971; Chopra,

The GenBank/EMBL/DDBJ accession number for the nucleotide sequence of fusH reported in this paper is 250108 .
1976). Some Staph. aureus strains carry plasmids that encode fusidic acid resistance (Chopra, 1976).

Wild-type Streptomyces lividans 66 is resistant to fusidic acid. Comparison of this strain and a fusidic-acidsensitive mutant allowed the identification of an extracellular enzyme that inactivates fusidic acid (von der Haar et al., 1991). Using a combination of ultrafiltration and chromatography on Phenylsepharose and an anion exchanger, the enzyme was highly purified. Its apparent molecular mass is $48 \mathrm{kDa}$ and its activity is optimal between $45^{\circ} \mathrm{C}$ and $55^{\circ} \mathrm{C}$ and between pH 6.0 and $9 \cdot 0$. It is stimulated by neither mono- nor divalent ions. The enzyme removes the acetyl group at C-16 from fusidic acid. The resulting intermediate is unstable and spontaneous lactonization between C-21 and C-16 occurs rapidly (von der Haar \& Schrempf, 1995).

In this paper, we report the characterization and 
overexpression of the gene encoding the specific esterase that inactivates fusidic acid and some of its derivatives.

\section{METHODS}

Strains and plasmids. Streptomyces lividans 66 was kindly provided by D. A. Hopwood, Norwich, UK. Streptomyces olivaceoviridis (Schnellmann et al., 1994) and Streptomyces reticuli and Streptomyces scabies have been described earlier (Schrempf, 1985). The E. coli plasmids pUC18 (YanischPerron et al., 1985) and pUS18 (Dittrich et al., 1991) and the Streptomyces-E. coli shuttle vector pWHM3 (Vara et al., 1989) were used. The construct pWF1 (see Fig. 2) consists of pWHM3 and a $3 \cdot 2 \mathrm{~kb} \mathrm{BamHI}$ fragment on which the cloned $S$. lividans fus $H$ gene is situated.

Culture conditions. Strains were grown on complete agar medium or in liquid minimal medium (von der Haar \& Schrempf, 1995; Hopwood et al., 1985). To attain optimal production of the inducible fusidic-acid-modifying enzyme, $3 \times 10^{7}$ spores $S$. lividans (pWHM3) or S. lividans (pWF1) $\mathrm{ml}^{-1}$ were added to 21 flasks containing $250 \mathrm{ml}$ minimal medium and shaken for $24 \mathrm{~h}$ at 120 r.p.m. An additional $250 \mathrm{ml}$ minimal medium and $50 \mu \mathrm{g}$ fusidic acid (Sigma) were added to each flask and the mixture was subdivided into $250 \mathrm{ml}$ volumes. Cultivation was then continued for another $36 \mathrm{~h}$ (von der Haar \& Schrempf, 1995).

Purification of the enyzme. After the culture $(500 \mathrm{ml})$ had been centrifuged at $10000 \mathrm{~g}$ for $20 \mathrm{~min}$, the supernatant was concentrated by ammonium-sulfate precipitation $(90 \%, \mathrm{w} / \mathrm{v})$ and resuspended in $500 \mu \mathrm{l} 20 \mathrm{mM}$ Tris/ $\mathrm{HCl}$ buffer, $\mathrm{pH} 7 \cdot 0$. Chromatographic purification of the enzyme was as recently described by von der Haar \& Schrempf (1995).

Enzyme assays. For the determination of fusidic-acidmodifying activities, samples were diluted with $50 \mathrm{mM}$ phosphate citrate buffer, $\mathrm{pH} 7$, to a total volume of $100 \mu \mathrm{l}$ and $100 \mu \mathrm{g}$ fusidic acid was added. After incubation at $30^{\circ} \mathrm{C}$ for $5 \mathrm{~h}$, the antibiotic and the products were extracted twice with $0.5 \mathrm{ml}$ ethyl acetate. The combined extracts were evaporated at $75^{\circ} \mathrm{C}$. The remaining substances were suspended in $10 \mu \mathrm{l}$ ethanol and analysed by TLC, as described by von der Haar $e t$ al. (1991). The reaction products were quantified by scanning the chromatograms and subsequent densitometric evaluation of the spots with the computer program Cybertech CAM2.0. One unit of activity was defined as the conversion of $1 \mu \mathrm{mol}$ fusidic acid to its inactive products per minute (von der Haar \& Schrempf, 1995).

SDSPAGE, transfer of proteins and amino acid sequencing. SDS-PAGE was performed with $10 \%$ polyacrylamide gels in the presence of $0 \cdot 1 \%$ SDS according to the method of Laemmli (1970). If protein sequences were to be determined, the protein was blotted onto a PVDF membrane (Immobilon P, Millipore), as described earlier (Schlochtermeier et al., 1992) The N-terminal sequences of the mature protein and of internal peptides generated by cleavage with LysC protease were determined by R. Schmid, Universität Osnabrück, Germany, and P. Jungblut, Wita, Germany, respectively.

Preparation of the oligonucleotide and hybridizations. The N-terminus of the longest internal peptide was used to synthesize a 39-mer oligonucleotide. The digoxigenin-labelled 39 -mer oligonucleotide was hybridized at $64^{\circ} \mathrm{C}$ with DNA fragments transferred from an agarose gel to a nylon membrane (Sambrook et al., 1989). After $20 \mathrm{~h}$ at $64^{\circ} \mathrm{C}$, the nylon membrane was washed twice in $2 \times \mathrm{SSC}(5 \mathrm{~min}$ at room temperature) and twice in $0.1 \times \operatorname{SSC}\left(15 \mathrm{~min}\right.$ at $\left.64^{\circ} \mathrm{C}\right)$. Immunodetection was carried out according to the specifications of the DNA labelling and detection kit supplied by Boehringer.

Transformation of strains. E. coli was transformed with plasmid DNA by the $\mathrm{CaCl}_{2}$ method (Sambrook et al., 1989). Streptomyces protoplasts were prepared and transformed in the presence of polyethylene glycol according to the standard procedure (Hopwood et al., 1985). An overlay of $0.4 \%$ agarose containing $500 \mu \mathrm{g}$ thiostrepton $\mathrm{ml}^{-1}$ was used to select transformants.

Isolation of DNA. Plasmids of E. coli and Streptomyces strains were isolated by the alkaline method with strain-specific modifications (Sambrook et al., 1989; Hopwood et al., 1985). Total DNA of Streptomyces strains was released by neutral lysis from cultures grown in a sucrose-containing complete medium for $2 \mathrm{~d}$ (Hopwood et al., 1985).

Preparation and screening of a subgenomic DNA library. Total DNA $(200 \mu \mathrm{g})$ from $S$. lividans was cleaved with SstII and separated on preparative agarose gels. Fragments of about $1.3-1.5 \mathrm{~kb}$ were extracted from the gel and ligated to SstIIlinearized pUS18 (Dittrich \& Schrempf, 1992). A subgenomic DNA library consisting of BamHI fragments of $3-3.5 \mathrm{~kb}$ was obtained in a similar fashion, using BamHI-linearized pUC18. Each of the ligation mixtures was used to transform E. coli XL1-Blue. Ampicillin-resistant transformants were tested for the presence of the desired insert by colony hybridization with the 39 -mer oligonucleotide at $64^{\circ} \mathrm{C}$.

General DNA techniques. Modification of DNA with nucleases, polymerases and ligases was carried out by standard procedures (Sambrook et al., 1989). DNA restriction fragments were resolved by agarose gel electrophoresis.

DNA was sequenced using the $\mathrm{T} 7$ sequencing kit from Pharmacia and digoxigenin-labelled oligonucleotides (MWG) that corresponded to primers of the lac $Z$ system.

Computer analysis. Sequences were compared using the FASTA program and the SWISS-PROT and EMBL databases; they were analysed with the GENMON program (GBF), and reading frames were determined with the GCWIND program (D. Shields, Dublin, Ireland) on the basis of the codon usage preferences in Streptomyces DNA.

\section{RESULTS AND DISCUSSION}

\section{Determination of amino acid sequences and identification of the associated gene}

The enzyme FusH purified from S. lividans culture supernatant solutions was subjected to Edman degradation. The $\mathrm{N}$-terminal sequence of the mature protein was determined to be XGEPAAATD. In addition, FusH was cleaved by the protease LysC and the $\mathrm{N}$-termini of several internal peptides were analysed. The $\mathrm{N}$-terminus (DLGRLYFADVDGDR) of the longest internal peptide obtained was used to deduce and synthesize the 39-mer oligonucleotide GAC CTS GGS CGS CTS TAC TTC GCS GAC GTS GAC GGS GAC. This was hybridized under various conditions with total DNA from $S$. lividans 66 cleaved with different restriction enzymes. As shown in Fig. 1, single BamHI, SmaI, and SstII fragments of the $S$. lividans genome hybridized with the 39-mer probe. 


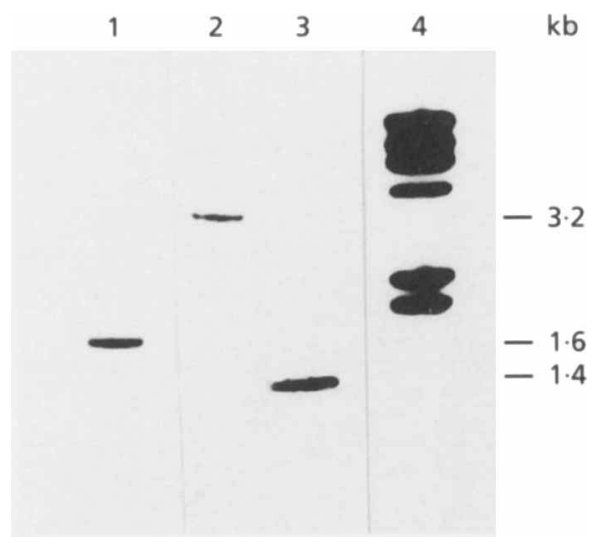

Fig. 1. Hybridization of the digoxigenin-labelled 39-mer oligonucleotide deduced from an internal peptide of purified FusH with S. lividans genomic DNA cleaved with Smal (lane 1), BamHI (lane 2) and Sstll (lane 3). Lane 4 contained HindlIIcleaved and digoxygenin-labelled $\lambda$ DNA. The markers on the right indicate the calculated sizes of the S. lividans fragments.

\section{Cloning and sequencing of the gene}

A subgenomic DNA library in E. coli XL1-Blue containing $1.3-1.5 \mathrm{~kb}$ Sst II fragments of $S$. lividans 66 cloned in pUS18 was hybridized with the 39-mer oligonucleotide. Three transformants carried the expected constructs, each of them containing the same $1.4 \mathrm{~kb}$ SstII insert. Because this insert was too small to contain the complete gene for FusH, the 3-3.5 kb fragments from $S$. lividans DNA cleaved with BamHI were cloned in pUC18 and used to transform E. coli XL1-Blue. Colony hybridization was performed with the SstII fragment as probe. Four transformants contained the expected construct carrying a $3.2 \mathrm{~kb} \mathrm{BamHI}$ insert in one or the other orientation. After colony hybridization and subsequent DNA analysis, the sequences of overlapping fragments obtained by subcloning were determined in both orientations (Fig. 2).

\section{Analysis of the sequence and the deduced protein}

One complete ORF was detected within the cloned sequence. It had a $\mathrm{G}+\mathrm{C}$ content of $71.6 \mathrm{~mol} \%$, which is typical of most Streptomyces genes. Two possible start codons (GUG at position 206 and UUG at position 239) with corresponding Shine-Dalgarno sequences (Fig. 3a) and one stop codon (UGA) could be identified. Most Streptomyces genes contain the start codon AUG, but sometimes GUG and UUG are used (Théberge et al., 1992; Fernández-Abalos et al., 1992). The sequenced ORF may encode a $55 \cdot 3$ or a $54 \cdot 2 \mathrm{kDa}$ protein with 520 or 509 amino acids, respectively. The pI of the mature protein was calculated to be $5 \cdot 39$. By aligning the deduced amino acid sequence with the amino acid sequence (IXGEPAAATD) determined by Edman degradation of the $\mathrm{N}$-terminus of the purified mature protein, the cleavage site (AQA, consensus AXA) for a signal (a)

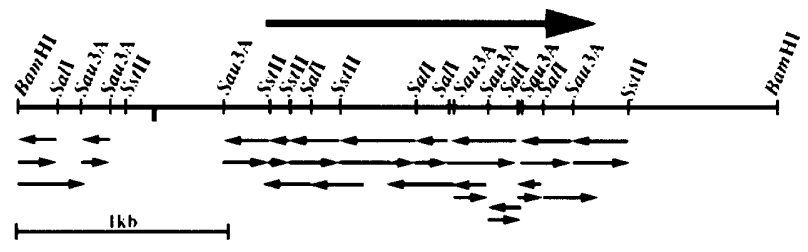

(b)

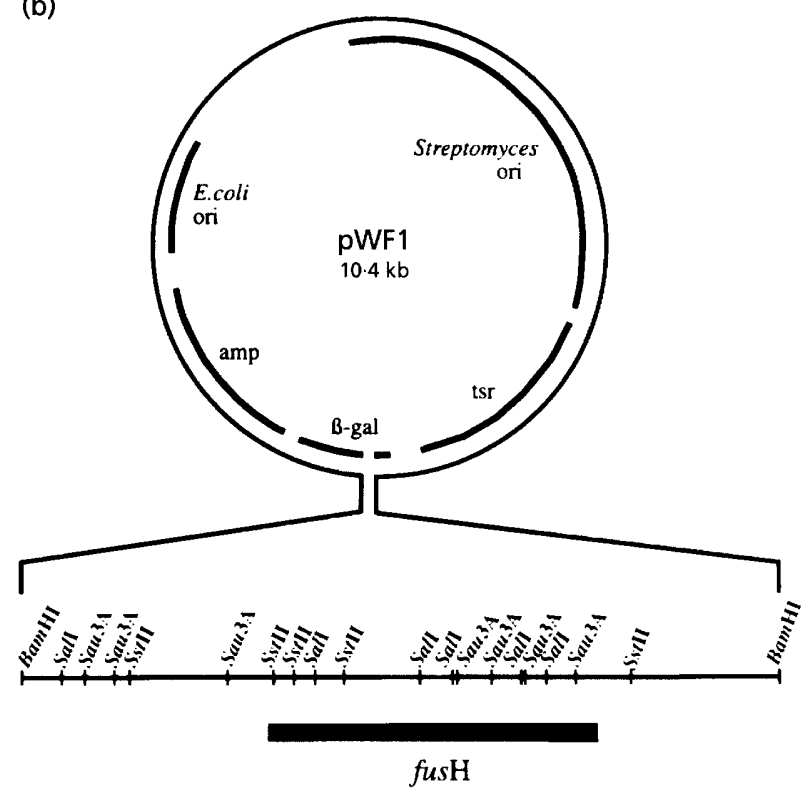

Fig. 2. (a) Strategy for sequencing a $2.1 \mathrm{~kb}$ segment of the cloned $3.2 \mathrm{~kb} \mathrm{BamHl}$ fragment. (b) The hybrid plasmid pWF1, which consists of the shuttle vector pWHM3 and the $3.2 \mathrm{~kb}$ $\mathrm{BamHI}$ fragment containing the $\mathrm{fus} H \mathrm{H}$ gene.

peptidase could be identified (Fig. 3a). The amino acid composition of the deduced signal peptide resembles that of other secreted enzymes. The predicted size of the mature protein is $50.7 \mathrm{kDa}$. Whether each of the start codons is used as a translational start is not known. A dual start motif has been identified in holin genes from lambdoid phages and in the Bacillus phage $\phi 29$ (Tedin $e t$ al., 1995), but is also known in streptomycetes (Raymer et al., 1990).

Three directly repeated sequences are present within the gene (Fig. 3b). Aligning these regions in the deduced protein revealed three identical consecutive blocks of 50 amino acids. Moreover, this region is preceded by a stretch of 47 amino acids showing $47 \%$ identity, and followed by stretches of 40 amino acids showing $63 \%$ identity with the region repeated three times. Studies with the products of truncated forms of the gene will be necessary to determine the role of these repeats, which have not as yet been reported in other deduced proteins.

Our biochemical investigations (see below) suggested that FusH is a specific esterase. We therefore compared regions of $\mathrm{FusH}$ with sequences deduced from other 
(a) $\begin{array}{ccccc}10 & 30 & 50 & 70 & 90\end{array}$
130
150
170
190
210
230

CTTTGCTGTGTAGCAGTTCGGGTGGTCTGTGTACGATGCGTCACGTGTCAGGTATTTCCATTGCCCATTCGGAAGGTCCTTTCGMGGCCACACTGATTCCGAAGAAGGGAAGTACGMTE

$250 \quad 270 \quad 390 \quad 310 \quad 330 \quad 350$

CTCAACAAAGGAATCCGCACGCGGCGGCTCGCGGGGCACTGGCCGGCGGCACGGTCCTGACGGCCGCCGCCGCCCTGCTCACCGCGGTGCCGGCCGCGCAGGCGATTTCCGGCGAGCCC

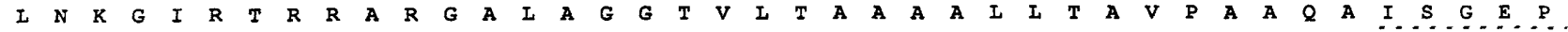

$\begin{array}{lllll}370 & 390 & 410 & 430 & 450\end{array}$

CCGGCCGCGACCGACCACGCCTTCACCGCCCGGCTGCACATCGGCGAGGGCGACACCCTCCGCGGCTGTTCCGCCGCTCTGGTGCACCAGCAGTGGCTGCTGACCGCCACGAGCTGTTTC

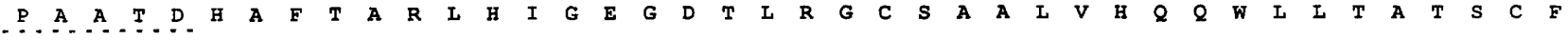
490
510
530
550
570
590

GCCGCCACCCCGGGTGGCGAGTTAAGTCGGGCAAGCCCGCGCTGAAGTCGACGGCGACCCTGGGCGGCAAGACCCTCGGCATAGTCGAGGTCGTTCCGCGCGACGACCGGGACGTGGCC

$\begin{array}{lllllllllllllllllllllllllllllllllllllllllll}A & A & T & P & G & G & E & V & K & S & G & K & P & A & I & K & S & T & A & T & L & G & G & K & T & I & G & I & V & E & V & V & P & R & D & D & R & D & V & A\end{array}$

$610 \quad 630 \quad 650 \quad 670 \quad 690 \quad 610$

ATGGTCCGGCTCGCCGAACCCGTCACCACGGTCGAGCCCGTGCGGCTGGCCGCGGACGCCCCCGTGGCGGCCGAGACCCTGCTCGGTGCAGGGTTCGGGCGGACCCGGACGGAGTGGGCC

$\begin{array}{lllllllllllllllllllllllllllllllllllllllllll}M & \text { V } & \text { R } & \text { L } & \text { A } & \text { E } & \text { P } & \text { V } & \text { T } & \text { T } & \text { V } & \text { E } & \text { P } & \text { V } & \text { R } & \text { L } & \text { A } & \text { A } & \text { D } & \text { A } & \text { P } & \text { V } & \text { A } & \text { A } & \text { E } & \text { T } & \text { L } & \text { L } & G & \text { A } & G & F & G & R & T & R & T & E & W & A\end{array}$

$\begin{array}{lllll}730 & 750 & 770 & 790 & 810\end{array}$

CCGGACCAGTTGCACACCGGCGAGTTCCGAGTGGACTCCGTCACCGGCACCACCGTGGAGCTGACCGGTCAGGACGGGGTGTCCGTGTGCAAGGGCGACACCGGCGGCCCGGCCCTGCGC

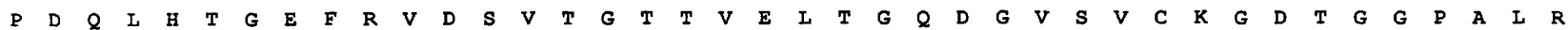

$850 \quad 870 \quad 890 \quad 910 \quad 930 \quad 950$

GGCACGGGTGGTGAGGTCGAGCTGGCCGCCTTGCACAGCCGGTCCTGGCAGGGCGGTGCTTCGGCGAGACGGAGACCCGGACCGGCGCGGTGGACGCCAGGGCCGACGGCCTGGCGGAC

$\begin{array}{llllllllllllllllllllllllllllllllllllllllll}G & T & G & G & E & V & E & L & A & A & V & H & S & R & S & W & Q & G & G & C & F & G & E & T & E & T & R & T & G & A & V & D & A & R & A & D & G & L & A & D\end{array}$

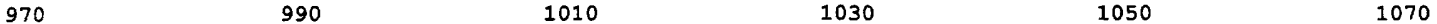

TGGGTGACGGACGTCCGCAACCGCGACCGGACGCAGTCGGCCGACGTCGACGGCGACGGCAGGGCCGACCTCGTCGTCCTGCGCTCGAACGGCGACGTCGTCGTCCACCGCAACCTGGGC

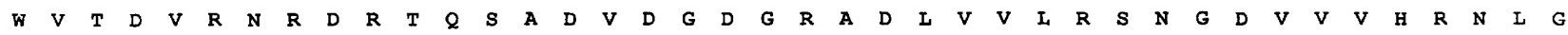

$1090 \quad 1110 \quad 1130 \quad 1150 \quad 1170 \quad 1190$

GACAGCTTCGCCGCCGGCCGGGTCATGTCCGGCGGCTGGGGCCTCTTCGTGACCTGGAAGGACCTGGGCCGGCTCTATTTCGCCGACGTCGACGGCGACCGCAAGGCCGACATGATCGTC

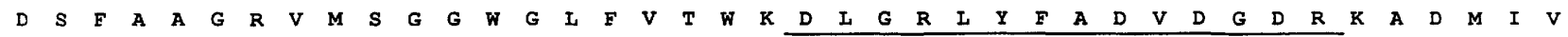

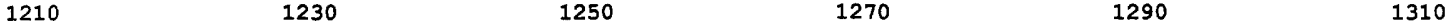

CACACCAGCGACGGCAACATCGAGGTCCGCTTCAACCACGGCACCTACTGGGACCAGGGCACGCACTGGTCCGGCGGCTGGGGCCGCTTCATCGACGGCAGCGACCTGGGCCGGCTCTAC

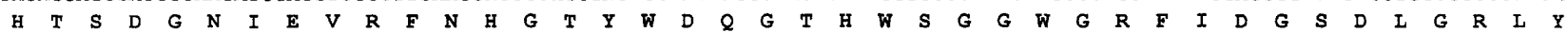

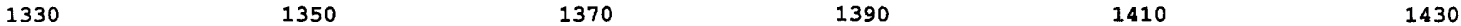

TTCGCCGATGTGGACGGCGACGGCAGGGCGGACATGATCGTCCACACCGGCGACGGCAACGTCGAGGTGCGCTTCAACCACGGCACGTACTGGGACCAGGGGACGCACTGGTCGGGCGGC

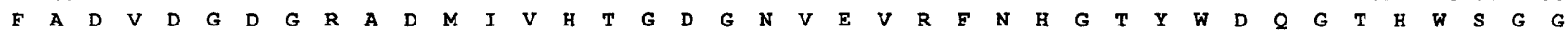

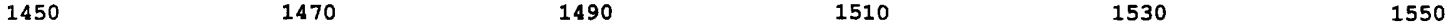

TGGGGCCGCTTCGTGACCTGGAAGACCTGGGCCGGCTCTACTTCGCCGATGTCGACGGCGACGGCAGGGCGACATGATCGTCCACACCGGCGACGGCAACGTAGAGGTCCGCTTCAAC

$\begin{array}{llllllllllllllllllllllllllllllllllllllllll}\text { W } & G & R & F & V & T & W & K & D & L & G & R & L & Y & F & A & D & V & D & G & D & G & R & A & D & M & I & V & H & T & G & D & G & N & V & E & V & R & F & N\end{array}$

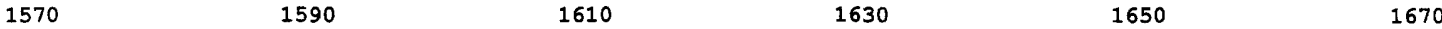

CACGGCACGTACTGGGACCAGGGCACGCACTGGTCCGGCGGCTGGGGCCGCTTCGTCGACGGCAGCGACCTGGGTTCCTCGAGTTCGGCGACGCCACCGGTGACGGCAAGGCCGACCTG

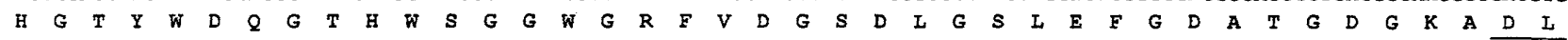

$$
1690 \quad 1710 \quad 1730 \quad 1750 \quad 1770 \quad 1790
$$

CTCGTCCGCACCAAGGACGGGAAGTTCGCCCTCCGTACCAACCACGGCACCTACTGGGACCAGGGCAAGTTCATGATCACGCTCTGACCTTCCTTCCCGCACACTCCTGAATGAGGACTC

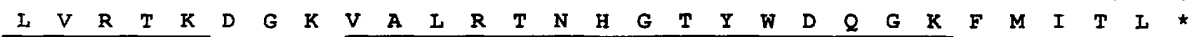

$\begin{array}{lllll}1810 & 1830 & 1850 & 1870 & 1890\end{array}$

CCATGTTTGCCATGCCGCGCTCCGCCCGGCTCACCGCCCTGTCCGCCGCCCTGCTGGCCGGCGCCCTGGCGTCCAGCTCCACCCCGGCTCTCGCCACCGCCGGCGCCCCGGCCACCGAAG

$\begin{array}{llll}1930 & 1950 & 1970 & 1990\end{array}$

CGAAACTGGACTTCGCCGTCCGTCTGACCATAGGGCACCGACTACCGCGCGTGCTCGGGCGCCCTGGTGGACGCGCAGTGGGTGCTCACCGCGG

(b)

\begin{tabular}{|c|c|}
\hline VATLIPKKGSTLLNKGIRTRRARGALAGGTVLTAAAALLTAV & \\
\hline PAAQAISGEPPAATDHAFTARLHIGEGDTLRGCSAALVHQQWLLTATSCEAATP & \\
\hline GGEVKSGKPALKSTATLGGKTLGIVEVVPRDDRDVAMVRLAEPVTTVEPVRLAA & \\
\hline DAPVAAETLLGAGFGRTRTEWAPDQLHTGEFRVDSVTGTTVELTGQDGVSVCKG & \\
\hline DTGGPALRGTGGEVELAAVHSRSWQGGCFGETETRTGAVDARADGLADWVTDVR & \\
\hline RDRTQSADVDGDGRADLVVLRSNGDVVVHRNLGDSFAAGRVMSGG & \\
\hline DLGRL YFADVDGDRKADMIVHTSDGNIEVRFNHGTYWDOGTHWSGGWGRF IDGS & \\
\hline DLGRLYFADVDGDGRADMIVHTGDGNVEVRFNHGTYWDOGTHWSGGWGRFVTWK & \\
\hline DLGRLY FADVDGDGRADMI VHTGDGNVEVRFNHGTYWDQGTHWSGGWGRFVDGS & \\
\hline DLGSLEFGDATGDGKADLLVRTKDGKVALRTAHGTYWDQGKFMITL & \\
\hline
\end{tabular}

Fig. 3. (a) Nucleotide sequence of the fus $\mathrm{H}$ gene and the deduced amino acid sequence. The $\mathrm{N}$-terminal amino acids of the internal peptides (determined by Edman degradation) are underlined. The $\mathrm{N}$-terminus of the protein is indicated by a dotted line. The two putative start codons are shown in grey boxes and the two possible sequences corresponding to the 3 -terminal end of the $16 \mathrm{~S}$ rRNA of S. lividans are double-underlined. (b) Alignment of repeated amino acid motifs within the FusH protein. 


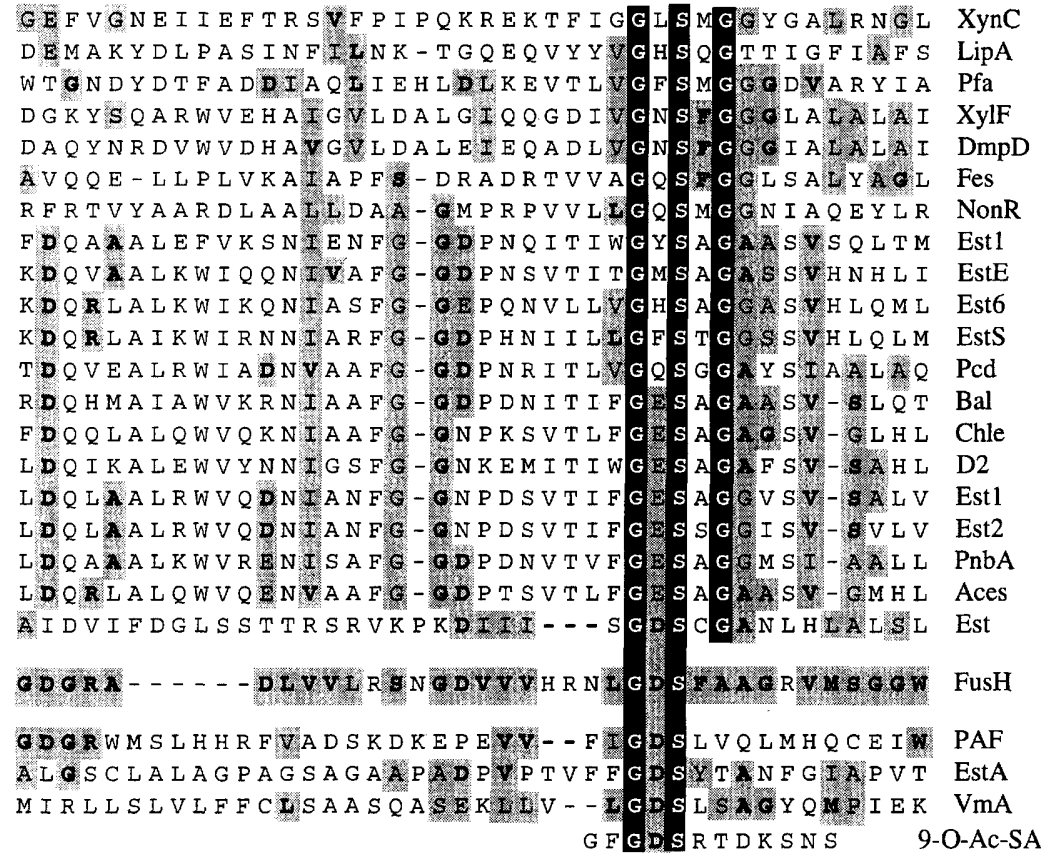

Fig. 4. Alignment of amino acids of the $\mathrm{GX}_{1} \mathrm{SX}_{2} \mathrm{G}$ or GDS motif from various deduced esterases. XynC, Caldocellum saccharolyticum (Lüthi et al., 1990); LipA, human (Anderson \& Sando, 1991); Pfa, Pseudomonas fluorescens (Pelletier \& Altenbuchner, 1995); XylF, Pseudomonas putida (Horn et al., 1991); DmpD, Pseudomonas putida (Nordlund \& Shingler, 1990); Fes, E. coli (Pettis et al., 1988); NonR, Streptomyces griseus (Plater \& Robinson, 1992); Est1, Caenorhabditis elegans (Kennedy et al., 1993); EstE, Myzus persicae (Field et al., 1993); Est6, Drosophila melanogaster (Collet et al., 1990); EstS, Drosophila virilis (Sergeev et al., 1993); Pcd, Arthrobacter oxidans (Pohlenz et al., 1992); Bal, rat (Fontaine et al., 1991); Chle, dog (Arpagaus et al., 1991); D2, Dictyostelium discoideum (Bomblies et al., 1990); Est1, rat (Takagi et al., 1988); Est2, rabbit (Ozols, 1989); PnbA, Bacillus subtilis (Zock et al., 1994); Aces, human (Soreq et al., 1990); Est, Acinetobacter calcoaceticus (Reddy et al., 1989); FusH, Streptomyces lividans (this paper); PAF, cow (Hattori et al., 1994); EstA Streptomyces scabies (Raymer et al., 1990); VmA, Vibrio mimicus (Shaw et al., 1994); 9O-Ac-SA, influenza (Hayes \& Varki, 1989). esterase genes (Fig. 4). The active centres of several proteases, lipases, acetyltransferases and esterases known to be serine hydrolases consist of a triad of the amino acids serine, histidine, and aspartic or glutamic acid. In the crystal structure of an acetylcholine esterase (Sussman et al., 1991) and lipases (Winkler et al., 1990; Brady et al., 1990), folding of the protein brings these residues close to each other. Within the primary structure deduced from esterase genes, however, only the serine residue of the active sites can be identified from its location in a $\mathrm{GX}_{1} \mathrm{SX}_{2} \mathrm{G}$ or a GDS motif. The FusH protein possesses the GDS motif (Fig. 4).

\section{Expression of fusH in the S. lividans wild-type and a fusidic-acid-sensitive mutant}

The $3 \cdot 2 \mathrm{~kb}$ BamHI fragment (Fig. 2) that contained the fusH gene was recloned in the multicopy Streptomyces-E. coli shuttle vector pWHM3 (Vara et al., 1989), resulting in the multicopy construct pWF1. The constructs were used to transform the $S$. lividans wild-type strain and its spontaneous fusidic-acid-sensitive variant $S$. lividans 90-2. Thiostrepton-resistant transformants furnished the anticipated plasmids. Comparative studies revealed that wild-type S. lividans and $S$. lividans(pWF1) showed resistance levels of 15 and $70 \mu \mathrm{g} \mathrm{ml}^{-1}$, respectively, to fusidic acid. In contrast, the S. lividans 90-2 mutant carrying pWF1 was resistant only to low levels $\left(5 \mu \mathrm{g} \mathrm{ml}^{-1}\right)$ of fusidic acid. The data suggested that $f u s H$ was overexpressed when present on a multicopy vector in wild-type $S$. lividans, but not in the mutant $S$. lividans 90-2.

Proteins in culture filtrates of wild-type S. lividans, its fusidic-acid-sensitive mutant $S$. lividans $90-2$ and the corresponding transformants carrying pWF1 were concentrated and analysed. Fusidic-acid-inactivating activity was highest $\left[1 \cdot 3 \mathrm{mU}(\mathrm{ml} \text { culture filtrate })^{-1}\right]$ in $S$. lividans (pWF1). The activity in strain 90-2(pWF1) was about 20-fold lower. The reaction products were extracted in ethyl acetate and analysed by TLC. Wild-type $S$. lividans, $S$. lividans(pWF1) and $S$. lividans 90-2(pWF1) converted fusidic acid $\left(R_{F}, 0.42\right)$ to two compounds of $R_{F} 0.20$ and $R_{F} 0.61$. The compound with $R_{F} 0.20$ had already been characterized as the enzymic reaction product that spontaneously converts to the lactone at $R_{F} 0.61$ (von der Haar et al., 1995). Fractionation of the extracellular proteins by SDS-PAGE showed that $S$. lividans(pWF1) contained the largest quantity of a $48 \mathrm{kDa}$ protein (Fig. 5). The size of this protein corresponded to that of FusH purified earlier (von der Haar et al., 1995) from wild-type S. lividans, and to the size $(50.7 \mathrm{kDa})$ calculated for the polypeptide deduced from fusH (see above). The data show that the cloned gene encodes a specific esterase which is overproduced if the gene is present in high copy number.

Transformants of the fusidic-acid-sensitive mutant $S$. lividans 90-2 showed only a very low level of esterase activity after transfer of precultured mycelia to media containing fusidic acid. The genome of S. lividans 90-2 contains the $3.2 \mathrm{~kb} \mathrm{BamHI}$ fragment on which the fusH gene is situated (hybridization data not shown). Therefore, unlike tetracycline- and chloramphenicol-sensitive variants in S. lividans (Kessler et al., 1989; Dittrich et al., 1992), the fusidic-acid-sensitive mutant does not arise by deletion of the complete fusH gene. Instead, it may be due to a mutation or deletion in a region required for 
(a)

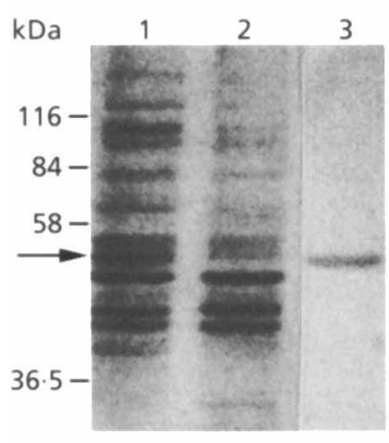

(b)

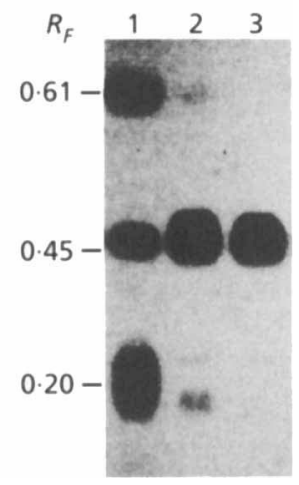

(a)

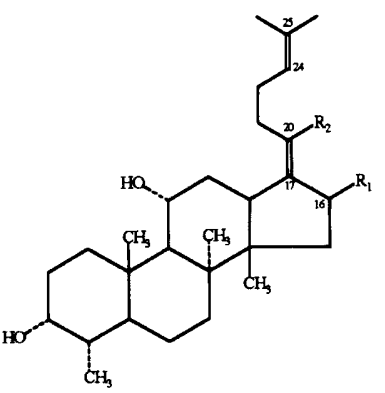

(b)

\begin{tabular}{|c|c|c|}
\hline $\begin{array}{l}\quad \mathbf{R}_{1} \\
\beta-\mathrm{O}-\mathrm{CO}-\mathrm{CH}_{3} \text { (fusidic acid) } \\
\beta-\mathrm{O}-\mathrm{CHO} \\
\beta-\mathrm{O}-\mathrm{CO}-\mathrm{CH}_{2}-\mathrm{CH}_{3} \\
\beta-\mathrm{S}-\mathrm{CO}-\mathrm{CH}_{3} \\
\beta-\mathrm{O}-\mathrm{CO}-\mathrm{CH}_{3} \\
\beta-\mathrm{O}-\mathrm{CO}-\mathrm{CH}_{3} \\
\beta-\mathrm{O}-\mathrm{CO}-\mathrm{CH}_{3}-17,20-24,25\end{array}$ & $\begin{array}{l}\mathbf{R}_{\mathbf{2}} \quad \text { Hydro } \\
\mathrm{COOH} \\
\mathrm{COOH} \\
\mathrm{COOH} \\
\mathrm{COOH} \\
\mathrm{CO}-\mathrm{NH}-\mathrm{CH}_{2}-\mathrm{COOH} \\
\mathrm{COOH} \\
\mathrm{COOH}\end{array}$ & $\begin{array}{l}5 \text { by FusH (\%) } \\
100 \\
64 \\
31 \\
90 \\
81 \\
9 \\
84\end{array}$ \\
\hline
\end{tabular}

(c)

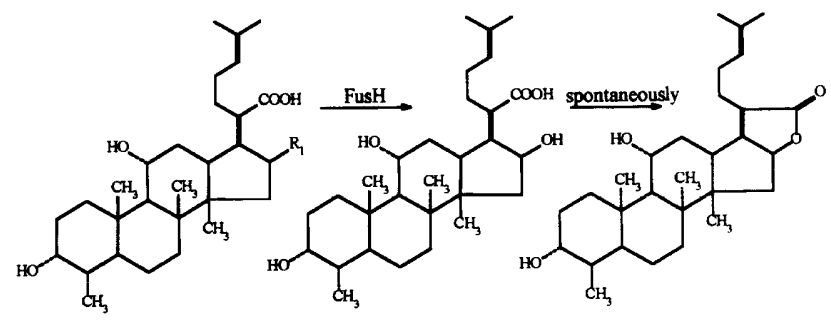

Fig. 6. (a) Structure of fusidic acid. (b) Fusidic acid derivatives and cleavage rates by FusH. A sample $(50 \mu \mathrm{g})$ of fusidic acid or of its derivatives was incubated with the esterase for $5 \mathrm{~h}$. After TLC analysis, the reaction products were quantified as described in Methods. The percentage of hydrolysis of various compounds was related to that of fusidic acid (100\%). (c) Reaction mechanism of FusH. The structure of the lactone derivative was determined by von der Haar et al. (1991).

\section{ACKNOWLEDGEMENTS}

We thank P. Jungblut, Wita, Berlin, Germany and R. Schmid, Universität Osnabrück, Germany for the sequencing of internal peptides and N-terminal amino acids, respectively. We are grateful to W. van Daehne and W. O. Godtfredsen, Leo Pharmaceutical Products, Ballerup, Denmark for a generous supply of fusidic acid derivatives. D. Müller did the photography. The research was supported by the Deutsche Forschungsgemeinschaft.

\section{REFERENCES}

Anderson, R. A. \& Sando, G. N. (1991). Cloning and expression of cDNA encoding human lysosomal acid lipase/cholesteryl ester hydrolase. J Biol Chem 266, 22479-22484.

Arpagaus, M., Chatonnet, A., Masson, P., Newton, M., Vaughan, T. A., Bartelst, C. F., Nogueira, C. P., La Du, B. N. \& Lockridge, O. (1991). Use of the polymerase chain reaction for homology probing of butyrylcholinesterase from several vertebrates. $J$ Biol Chem 266, 6966-6974. 
Bomblies, L., Biegelmann, E., Doering, V., Gerisch, G., KrafftCzepa, H., Nögel, A. A., Schleicher, M. \& Humbel, B. M. (1990). Membrane-enclosed crystals in Dictyostelium discoideum cells, consisting of developmentally regulated proteins with sequence similarities to known esterases. J Cell Biol 110, 669-679.

Brady, L., Brzozowski, A. M., Derewenda, Z. S., Dodson, E., Dodson, G., Tolley, S., Turkenburg, J. P., Christiansen, L., HugeJensen, B., Norskov, L., Thim, L. \& Menge, U. (1990). A serine protease triad forms the catalytic centre of a triacylglycerol lipase. Nature 343, 767-770.

Burton, H. S. \& Abraham, E. P. (1951). Isolation of antibiotics from a species of Cephalosporium. Cephalosporin $\mathrm{P}_{1}, \mathrm{P}_{2}, \mathrm{P}_{3}, \mathrm{P}_{4}$ and $\mathrm{P}_{5}$. Biochem J 50, 168-174.

Chopra, I. (1976). Mechanisms of resistance to fusidic acid in Staphylococcus aureus. J Gen Microbiol 96, 229-238.

Collet, C., Nielsen, K. M., Russell, R. J., Karl, M., Oakeshott, J. G. \& Richmond, R. C. (1990). Molecular analysis of duplicated esterase genes in Drosophila melanogaster. Mol Biol Evol 7, 9-28.

von Daehne, W., Godtfredsen, W. O. \& Rasmussen, P. R. (1979). Structure-activity relationships in fusidic acid-type antibiotics. Adv Appl Microbiol 25, 95-145.

Dittrich, W. \& Schrempf, H. (1992). The unstable tetracycline resistance gene of Streptomyces lividans 1326 encodes a putative protein with similarities to translational elongation factors and Tet $(\mathrm{M})$ and $\mathrm{Tet}(\mathrm{O})$ proteins. Antimicrob Agents Chemother 36, 1119-1124.

Dittrich, W., Betzler, M. \& Schrempf, H. (1991). An amplifiable and deletable chloramphenicol-resistance determinant of Streptomyces lividans 1326 encodes a putative transmembrane protein. Mol Microbiol 5, 2789-2797.

Fernández-Abalos, J. M., Sánchez, P., Coll, P. M., Villanueva, J. R., Pérez, P. \& Santamaría, R. I. (1992). Cloning and nucleotide sequence of $c e l \mathrm{~A}_{1}$, an endo- $\beta$-1,4-glucanase-encoding gene from Streptomyces halstedii JM8. J Bacteriol 174, 6368-6376.

Field, L. M., Williamson, M. S., Moores, G. D. \& Devonshire, A. L. (1993). Cloning and analysis of the esterase genes conferring insecticide resistance in the peach-potato aphid, Myzus persicae (Sulzer). Biochem J 294, 569-574.

Fontaine, R. N., Carter, C. P. \& Hui, D. Y. (1991). Structure of the rat pancreatic cholesterol esterase gene. Biochemistry $\mathbf{3 0}$, $7008-7014$.

Godtfredsen, W. O., Jahnssen, S., Lorck, H., Roholt, K. \& Tybring, L. (1962). Fusidic acid: a new antibiotic. Nature 193, 897.

von der Haar, B. \& Schrempf, H. (1995). Purification and characterization of an extracellular Streptomyces lividans 66 enzyme inactivating fusidic acid. J Bacteriol 177, 152-155.

von der Haar, B., Rosenberg, D., Dittrich, W. \& Schrempf, H. (1991). Inactivation of fusidic acid by resistant Streptomyces strains. J Antibiot 44, 785-792.

Hattori, M., Adachi, H., Tsujimoto, M., Arai, H. \& Inoue, K. (1994). The catalytic subunit of bovine brain platelet-activating factor acetylhydrolase is a novel type of serine esterase. J Biol Chem $\mathbf{2 6 9}$, 23150-23155.

Hayes, B. K. \& Varki, A. (1989). O-acetylation and de-Oacetylation of sialic acids. J Biol Chem 264, 19443-19448.

Hopwood, D. A., Bibb, M. J., Chater, K. F., Kieser, T., Bruton, C. J., Kieser, H. M., Lydiate, D. J., Smith, C. P., Ward, J. M. \& Schrempf, H. (1985). Genetic Manipulation of Streptomyces: a Laboratory Manual. Norwich: John Innes Foundation.

Horn, J. M., Harayama, S. \& Timmis, K. N. (1991). DNA sequence determination of the TOL plasmid (pWW0) $x y l G F J$ genes of
Pseudomonas putida: implications for the evolution of aromatic catabolism. Mol Microbiol 5, 2459-2474.

Kennedy, B. P., Aamodt, E. J., Allen, F. L., Chung, M. A., Heschl, M. F. P. \& McGhee, J. D. (1993). The gut esterase gene (ges-1) from the nematodes Caenorhabditis elegans and Caenorhabditis briggsae. J Mol Biol 229, 890-908.

Kessler, A., Dittrich, W., Betzler, M. \& Schrempf, H. (1989). Cloning and analysis of a deletable tetracycline-resistance determinant of Streptomyces lividans 1326. Mol Microbiol 3, 1103-1109.

Laemmli, U. K. (1970). Cleavage of structural proteins during the assembly of the head of bacteriophage T4. Nature 227, 680-685.

Lüthi, E., Love, D. R., McAnulty, J., Wallace, C., Caughey, P. A., Saul, D. \& Bergquist, P. L. (1990). Cloning, sequence analysis, and expression of genes encoding xylan-degrading enzymes from the thermophile "Caldocellum saccharolyticum". Appl Environ Microbiol 56, 1017-1024.

Malkin, M. \& Lipman, F. (1969). Fusidic acid: inhibition of factor $\mathrm{T}_{2}$ in reticulocyte protein synthesis. Science $164,71-72$.

Nordlund, I. \& Shingler, V. (1990). Nucleotide sequences of the meta-cleavage pathway enzymes 2 -hydroxymuconic semialdehyde dehydrogenase and 2-hydroxymuconic semialdehyde hydrolase from Pseudomonas CF600. Biochim Biophys Acta 1049, 227-230.

Ozols, J. (1989). Isolation, properties and the complete amino acid sequence of a second form of $60 \mathrm{kDa}$ glycoprotein esterase. Orientation of the $60 \mathrm{kDa}$ proteins in the microsomal membrane. J Biol Chem 264, 12533-12545.

Pelletier, I. \& Altenbuchner, J. (1995). A bacterial esterase is homologous with non-haem haloperoxidases and displays brominating activity. Microbiology 141, 459-468.

Pettis, G. S., Brickman, T. J. \& McIntosh, M. A. (1988). Transcriptional mapping and nucleotide sequence of the Escherichia coli fepA-fes enterobactin region. J Biol Chem 263, 18857-18863.

Plater, R. \& Robinson, J. A. (1992). Cloning and sequence of a gene encoding macrotetrolide antibiotic resistance from Streptomyces griseus. Gene 112, 117-122.

Pohlenz, H.-D., Boidol, W., Schüttke, I. \& Streber, W. R. (1992). Purification and properties of an Arthrobacter oxidans P52 carbamate hydrolase specific for the herbicide phenmedipham and nucleotide sequence of the corresponding gene. J Bacteriol 174, 6600-6607.

Raymer, G., Willard, J. M. A. \& Schottel, J. L. (1990). Cloning, sequencing, and regulation of expression of an extracellular esterase gene from the plant pathogen Streptomyces scabies. J Bacteriol 172, 7020-7026.

Reddy, P. G., Allon, R., Mevarech, M., Mendelovitz, S., Sato, Y. \& Gutnick, D. L. (1989). Cloning and expression in Escherichia coli of an esterase-coding gene from the oil-degrading bacterium Acinetobacter calcoaceticus. Gene 76, 145-152.

Sambrook, J., Fritsch, E. F. \& Maniatis, T. (1989). Molecular Cloning: a Laboratory Manual, 2nd edn. Cold Spring Harbor, NY : Cold Spring Harbor Laboratory.

Schlochtermeier, A., Walter, S., Schröder, J., Moormann, M. \& Schrempf, H. (1992). The gene encoding the cellulase (Avicelase) Cel1 from Streptomyces reticuli and analysis of protein domains. Mol Microbiol 6, 3611-3621.

Schnellmann, J., Zeltins, A., Blaak, H. \& Schrempf, H. (1994). The novel lectin-like protein CHB1 is encoded by a chitin-inducible Streptomyces olivaceoviridis gene and binds specifically to $\alpha$ chitin of fungi and other organisms. Mol Microbiol 13, 807-819. 
Schrempf, H. (1985). Genetic instability: amplification, deletion, and rearrangement within Streptomyces DNA. In Microbiology -1985, pp. 436-440. Edited by L. Leive, P. F. Bonventre, J. A. Morello, S. Schlesinger, S. D. Silver \& H. C. Wu. Washington, DC: American Society for Microbiology.

Sergeev, P. V., Yenikolopov, G. N., Peunova, N. I., Kuzin, B. A., Khechumian, R. A., Korochkin, L. I. \& Georgiev, G. P. (1993). Regulation of tissue specific expression of the esterase $S$ gene in Drosophila virilis. Nucleic Acids Res 21, 3545-3551.

Shaw, J.-F., Chang, R.-C., Chuang, K.-H., Yen, Y.-T., Wang, Y.-J. \& Wang, F.-G. (1994). Nucleotide sequence of a novel arylesterase gene from Vibrio mimicus and characterization of the enzyme expressed in Escherichia coli. Biochem J 298, 675-680.

Soreq, H., Ben-Aziz, R., Prody, C. A., Seidman, S., Gnatt, A., Neville, L., Lieman-Hurwitz, J., Lev-Lehman, E., Ginzberg, D., Lipidot, L. \& Zakut, H. (1990). Molecular cloning and construction of the coding region for human acetylcholinesterase reveals $\mathrm{G}+\mathrm{C}$ rich attenuating structure. Proc Natl Acad Sci USA 87, 9688-9692.

Sussman, J. L., Harel, M., Frolow, F., Oefner, C., Goldman, A., Toher, L. \& Silman, I. (1991). Atomic structure of acetylcholinesterase from Torpedo californica: a prototypic acetylcholinebinding protein. Science 253, 872-879.

Takagi, Y., Morohashi, K., Kawabata, S., Go, M. \& Omura, T. (1988). Molecular cloning and nucleotide sequence of cDNA of microsomal carboxyesterase E1 of rat liver. J Biochem 104, 801-806.

Tanaka, N., Kinoshita, T. \& Masukawa, H. (1969). Mechanism of inhibition of protein synthesis by fusidic acid and related steroidal antibiotics. J Biochem 65, 459.

Tanaka, N., Kawano, G. \& Kinoshita, T. (1971). Chromosomal location of a fusidic acid resistant marker in Escherichia coli. Biochem Biophys Res Commun 42, 564-567.

Tedin, K., Resch, A., Steiner, M. \& Blăsi, U. (1995). Dual translational start motif evolutionarily conserved in the holin gene of Bacillus subtilis phage phi 29. Virology 106, 479-484.

Théberge, M., Lacaze, P., Shareck, F., Morosoli, R. \& Kluepfel, D. (1992). Purification and characterization of an endoglucanase from Streptomyces lividans 66 and DNA sequence of the gene. Appl Environ Microbiol 58, 815-820.

Vara, J., Lewandowska-Skarbek, M., Wang, Y.-G., Donadio, S. \& Hutchinson, C. R. (1989). Cloning of genes governing the deoxysugar portion of the erythromycin biosynthesis pathway in Saccharopolyspora erythraea (Streptomyces erythreus). J Bacteriol 171, 5872-5881.

Waksman, S. A., Horning, E. S. \& Spencer, E. L. (1943). Two antagonistic fungi, Aspergillus fumigatus and Aspergillus clavatus and their antibiotic substances. J Bacteriol 45, 233-248.

Winkler, F. K., D'Arcy, A. \& Hunziker, W. (1990). Structure of human pancreatic lipase. Nature 343, 771-774.

Yanisch-Perron, C., Vieira, J. \& Messing, J. (1985). Improved M13 phage cloning vectors and host strains: nucleotide sequences of the M13mp18 and pUC19 vectors. Gene 33, 103-119.

Zock, J., Cantwell, C., Swartling, J., Hodges, R., Pohl, T., Sutton, K., Rosteck, P., Mcgilvray, D. \& Queener, S. (1994). The Bacillus subtilis $p n b \mathrm{~A}$ gene encoding $p$-nitrobenzylesterase-cloning, sequence and high-level expression in Escherichia coli. Gene 151, $37-43$.

Received 24 July 1996; revised 9 October 1996; accepted 21 October 1996. 